\title{
Mid-term results of TAVI in high-risk patients: data from a single center study
}

\author{
R Akchurin", T Imaev, P Lepilin, A Kolegaev, A Komlev, I Pokidkin \\ From 23rd World Congress of the World Society of Cardio-Thoracic Surgeons \\ Split, Croatia. 12-15 September 2013
}

\section{Background}

Transcatheter aortic valve implantation (TAVI) has become a method of choice in repair of valvular aortic stenosis, especially in group of patients with high surgical risk.

\section{Aim}

The objective was to evaluate the immediate and midterm results of applying TAVI in aortic valve surgery.

\section{Methods}

80 patients with a median age of $78 \pm 5.2$ years were included. All patients had severe aortic stenosis. According to the echo an average gradient of systolic pressure on the aortic valve was $>20 \%$ by EuroSCORE and $>10 \%$ by STS. We have implanted Edwards Sapiens/Sapiens XT or Medtronic CoreValve bioprostheses. In 58 cases implantation was performed through transfemoral access (including 30 Edwards Sapien cases) and in 17 cases- transapical access was used due to vascular abnormalities. In the rest 5 patients we used direct transaortic (4 cases) and in 1 case transsubclavian approach.

\section{Results}

Intraoperative mortality was $1.25 \%: 1$ patient (women) died with symptoms of acute heart failure. Total 30 days mortality rate was 5\%: 2 patients died within 7 days after TAVI - IM and other 2 patients developed cardiogenic shock. Incidence of non-fatal stroke was $2.5 \%$. In 2 patients the procedure of hemodialysis needed to be performed because of acute contrast-induced renal injury. Other patients had no significant complications. The AMPG after Edwards Sapien and Medtronic CoreValve implantations were $10,9 \pm 3,5$ and $14,3 \pm 5,4 \mathrm{~mm}$

\footnotetext{
* Correspondence: cardio@nm.ru

Cardiovascular Surgery, Russian Cardiology Research Center Moscow, Russian Federation
}

(c) 2013 Akchurin et al; licensee BioMed Central Ltd. This is an Open Access article distributed under the terms of the Creative Commons Attribution License (http://creativecommons.org/licenses/by/2.0), which permits unrestricted use, distribution, and reproduction in any medium, provided the original work is properly cited.

\section{and take full advantage of:}

- Convenient online submission

- Thorough peer review

- No space constraints or color figure charges

- Immediate publication on acceptance

- Inclusion in PubMed, CAS, Scopus and Google Scholar

- Research which is freely available for redistribution

Submit your manuscript at www.biomedcentral.com/submit 